\section{Survival of the Fittest: The University of Buenos Aires Model for the Future of Higher Education}

\section{Philip G. Altbach}

Philip G. Altbach is J. Donald Monan, S.J. professor of higher education and director of the Center for International Higher Education at Boston College.

$\mathrm{T}$ he University of Buenos Aires (UBA), Argentina's largest and most prestigious institution of higher education has put into place an educational model that, in a perverse way, has lessons for higher education policy worldwide. UBA is an institution of more than 180,000 students. It has been shaped by the educational ideas of the 1918 Cordoba reform, and these have calcified into rigid policy. Study at UBA is based on the Darwinian principle of survival of the fittesteveryone can enter, but only a small minority of the students who enroll eventually earn degrees — and they do this often by sheer persistence.

The UBA model should appeal to World Bank planners and other budget cutters since it provides both access to many and a decent education to a few-all at a low per capita expenditure. The cost per graduate may be high but the expenditure per student is very low in most faculties. The infrastructure is terrible (poor libraries and laboratories), but large numbers are processed through the institution.

\section{Key Characteristics}

Here are some key characteristics of the Buenos Aires model: - The University has totally open enrollment. Any high school graduate may enroll in any faculty without restriction-even in medicine or architecture. Unlike most European countries with similar open systems, Argentina has no rigorous high school completion exam and imposes no restrictions on fields such as medicine, where unlimited numbers directly affect quality of instruction.

- UBA is completely free, with no tuition or fees for study at any level.

- Most professors work part-time, teaching a course or two per term for a token payment. In most of the faculties, fewer than 20 percent are full-time professors. And full-time does not really mean a full-time commitment to the university, since professorial salaries are low-averaging around $\$ 24,000$ per year for the senior faculty. This means that even full time professors must hold other jobs. There are few restrictions on such extra employment.

- There is no tenure system or security of employment. Full-time faculty members are reevaluated every seven years in an open "contest" with others who may apply for their jobs, and they must compete with all applicants.

- Facilities are completely inadequate for students and faculty. Part-time staff have no place to meet students or prepare for class. Many full-time faculty are without offices of their own. Campus computing and other facilities are minimal. Libraries are woefully inadequate. Laboratories are similarly poorly equipped. Both students and faculty must rely on their own resources for books and Internet access.

- The dropout rate is very high and those students who complete their studies take a long time to do so. Most students hold jobs while studying, and few devote their full attention to the university. In some faculties, such as medicine, the dropout rate approaches 90 percent. Other faculties graduate somewhat higher proportions of students.

- There is a one-year sequence of a kind of general education (ciclo basico comun, CBC) for entering students. The courses are overcrowded, taught by part-time staff, and by all accounts not appealing to most students. Sixty percent of those who start the CBC either drop out or do not pass the examinations, and are as a result not permitted to enter one of the faculties. Most students have virtually no contact with professors until late in their academic program, if then.

- UBA remains the most prestigious university in the nation, and although it is losing ground to several of the new private institutions, graduates earn considerable status by holding a degree from the university. Even those who study there without actually completing a degree are held in some esteem. The fact is that UBA graduates are both bright and have accomplished a great deal by surviving in a difficult academic environment and obtaining their degrees.

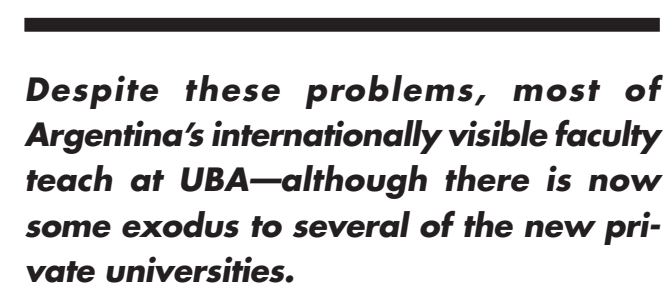

\section{Implications}

The UBA "model" has a number of implications. The minority of full-time staff must submit to the "contest" every seven years (although somehow most faculty manage to keep their jobs), and they must report on their research activities every other year. They are also expected to teach courses at all levels, advise master's students, and direct research programs. There is little intellectual community because of the difficult working conditions, and the pressured environment in which many professors work. Despite these problems, most of Argentina's internationally visible faculty teach at UBAalthough there is now some exodus to several of the new pri- 
vate universities. Part-time staff are happy to teach a course or two because of the prestige of holding an "appointment" at UBA.

The university cares little about its students. It has no control over how many students enter each year. And it cannot control the quality of its entering students. Its only power is to eliminate students through examinations, attrition, or inattention. The students who do well tend to be those from well-off families. In this way, the university contributes to social inequality even though it has an ideology of egalitarianism. The Argentine educational system, in general, works against the poor. Half of those who enter the schools do not complete their studies. And the large majority of those who enter UBA do not finish.

Those students who do complete their studies are both bright and persistent; they have to be to survive in the Darwinian system. When I expressed concern about the quality of Argentine medical doctors produced by such an unselective medical education system, I was told not to worry. The tiny minority who eventually graduate from the medical faculty are intelligent, highly motivated, and well trained. They are the survivors who are taken in hand by the professors toward the end of their course of study. The situation in other faculties is similar although perhaps not quite as egregious.

The government spends little on public higher education, and is especially harsh on UBA. Argentine higher education is highly politicized, and UBA is traditionally loyal to the Radical party, currently in the opposition. The ruling Peronists are naturally not inclined to support their political enemies. Elections are coming up in 1999, and the situation may change, although overall levels of support for public higher education are certain to remain low. Not only are many of the public universities identified by their party loyalties, but the governance system that was put in place by the reform movement of 1918 further politicized academe. The reform enshrined the participation of students and nonacademic university employees in the structures of governance of UBA and all of public higher education. Students, secretaries, and other employees, and professors all vote for the rector (president) and other key officeholders. Often, candidates for high university office fight for positions based on their political affiliations.

\section{Does it Work?}

Yet, in a strangeway, this is an academic system that works. It offers access to many and a quality education to a few. Those who drop out before finishing their degrees do not seem to resent either the university or the government. UBA acts as a mass "parking lot" for young people who would otherwise have problems finding jobs in Argentina's difficult employment market. The university "absorbs demand" at the same time that it dampens potential social unrest.

UBA keeps costs down. While it is true that the university goes against international trends by providing free tuition, it is fairly cost-effective in terms of providing access to large numbers cheaply. It does this by providing minimal services to the students, by paying full-time faculty salaries that are inadequate, and exploiting large numbers of part-time teachers who are happy to have a UBA affiliation. Money is saved by not investing in libraries, laboratories, or information technology. At UBA, "distance education" means that students and staff travel long distances to sit in crowded lecture halls.

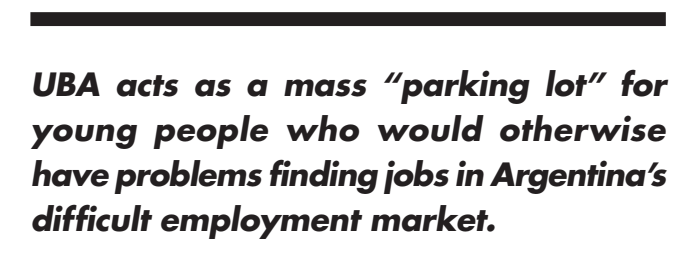

The status quo at UBA is reinforced by a combination of powerful forces that make change difficult. The traditions, some of which are enshrined in university regulations or in the Argentine legal system, remain strong. Among these are open access, free tuition, no job security for professors, and the idea of "autonomy." In Argentina, and in much of Latin America, autonomy means that the university has legal protection from direct governmental interference in many of its activities. Until recently, there was no accountability to anyone. A new accrediting and evaluation system, run by the government, will introduce some accountability.

The relationship between UBA and the government is influenced both by the ideology of autonomy and by the politicization of the university. UBA is traditionally linked to one of the political parties, and partisan politics infuses both campus decision making and the relations between the university and the government. Since the government provides all of the funding for the university, less than cordial relations create major problems. The Peronist government has cut UBA's budget, causing further deterioration in the quality of education at the university.

Despite all of these problems, in some ways the University of Buenos Aires does offer a range of academic programs to large numbers of students. It has an inefficient yet effective "selection" process that works by letting everyone in and weeding out those who are not highly motivated. The university invests little in terms of salaries for teachers, libraries, or infrastructure. Thus, for those who preach the gospel of low-cost postsecondary education in order to provide access to the maximum numbers, the University of Buenos Aires may provide a useful model. Indeed, for governments seeking to maximize access without regard to quality, UBA is also worth studying. The UBA model would be even more appealing to the budget cutters if tuition could be charged. Darwin would be proud of the University of Buenos Aires. 